\title{
Model Peningkatan Loyalitas Kerja Dosen PTS Menggunakan Structural Equation Modeling
}

\author{
Syarifah Mauli Masyithah \\ Sekoah Tinggi Ilmu Ekonomi Sabang, Banda Aceh \\ e-mail: syarifah@stiesabang.ac.id \\ Eliana \\ Sekolah Tinggi Ilmu Ekonomi Sabang, Banda Aceh \\ e-mail: eliana@stiesabang.ac.id
}

\begin{abstract}
This study aims to find a model for increasing the lecturers work loyalty of private university by using Structural Equation Modeling. The research sample was 150 lecturers of five private universities in Banda Aceh. The questionnaire is the main instrument for data collection. Furthermore, the data were analyzed using a structural equation model (SEM) operationalized with AMOS 21. The study revealed that lecturer work loyalty was positively and significantly affected by job satisfaction and their assessment of rewards and work environment. Therefore, an increase in lecturer work loyalty can be done through university foundation policy intervention in increasing rewards and improving the work environment quality of the university
\end{abstract}

Keywords: Lecturer's Work Loyalty, Rewards, Work Environment, SEM

\section{PENDAHULUAN}

Upaya peningkatan kualitas pendidikan tinggi merupakan kebutuhan mendasar bagi kemajuan universitas. Peningkatan kualitas pendidikan hanya dapat dicapai dengan adanya dosen berkualitas yang mampu mendukung kelancaran proses belajar mengajar secara baik. Selain itu, loyalitas kerja dosen juga merupakan kunci utama dalam penyelenggaran proses pendidikan tinggi. Mengingat pentingnya loyalitas kerja, maka peningkatan loyalitas kerja dosen menjadi perhatian serius bagi setiap pimpinan Perguruan Tinggi Swasta (PTS).

Secara teoritis dan didukung dengan sejumlah hasil penelitian empiris, loyalitas kerja seseorang terhadap instansi tempat mereka bekerja dapat dikaitkan dengan kepuasan kerja, lingkungan kerja dan imbalan. Keterkaitan antara kepuasan kerja dengan loyalitas kerja seperti dikemukakan oleh Wood et al. yang dikutip oleh Sawitri dan Utomo (2012) bahwa kepuasan kerja meningkatkan loyalitas kerja dan kinerja karyawan. Semakin tinggi kepuasan kerja yang dirasakan oleh karyawan akan semakin besar keinginan karyawan tersebut untuk bekerja secara sungguh-sungguh dan pada akhirnya berdampak pada loyalitas kerja mereka. Temuan penelitian Chen (2014) juga mengindikasikan adanya hubungan searah antara loyalitas kerja dan kepuasan kerja karyawan.

Selain berpengaruh terhadap loyalitas kerja, kepuasan kerja juga dipengaruhi oleh lingkungan kerja. Pada umumnya setiap dosen menginginkan lingkungan kerja yang baik. Adanya hubungan fungsional antara kepuasan kerja dan lingkungan kerja seperti dikemukakan oleh Bakotic dan Tomislav (2013) bahwa terdapat hubungan yang erat antara lingkungan kerja dengan kepuasan kerja. Lingkungan kerja adalah determinan 
penting bagi kepuasan kerja (Kreitner \& Kanicki, 2012).

Lingkungan kerja tidak hanya dapat mempengaruhi kepuasan kerja karyawan, tetapi juga dapat berdampak terhadap loyalitas kerja. Hal ini didukung oleh hasil kajian Waqas et al. (2014) juga membuktikan bahwa lingkungan tempat kerja (work place environment) berpengaruh signifikan terhadap loyalitas kerja. Karyawan akan cenderung mempertahankan keberadaan mereka pada lingkungan kerja yang mereka anggap dapat memberikan ketenangan dalam bekerja. Sehinga semakin baik penilaian mereka terhadap lingkungan kerja, semakin tinggi pula loyalitas terhadap pekerjaan.

Selain penilaian terhadap lingkungan kerja, faktor imbalan atau kompensasi juga dapat mempengaruhi kepuasan dan loyalitas kerja seseorang karyawan. Dengan kata lain, imbalan atau kompensasi yang diterima oleh karyawan juga berdampak pada kepuasan dan loyalitas kerja. Adanya pengaruh imbalan terhadap loyalitas kerja seperti dikemukakan oleh Steers dan Porter (2013) bahwa loyalitas kerja dipengaruhi oleh beberapa faktor diantaranya imbalan yang diperoleh dari aspek pekerjaan.

Di antara sejumlah PTS di Banda Aceh, terdapat 5 (lima) PTS yang memiliki jumlah mahasiswa relatif banyak atau sangat banyak diminati oleh kalangan mahasiswa, yakni Universitas Serambi Mekah, Universitas Abulyatama, Universitas Muhamadiyah Aceh, Universitas Ubudiyah dan Universitas Iskandar Muda. Ketersediaan tenaga dosen atau staf pengajar tetap di masing-masing perguruan tinggi tersebut tentunya sangat penting dalam mendukung kegiatan operasionalnya. Karena itu, kepuasan dan loyalitas kerja dosen di masing-masing perguruan tinggi sangat penting untuk dianalisis. Hasil survei awal mengindikasikan bahwa kepuasan kerja dan loyalitas kerja dosen pada masing-masing perguruan tinggi tersebut relatif berbeda satu sama lain. Di satu sisi ada dosen yang memiliki kepuasan kerja dan loyalitas kerja yang rendah dan disisi lain juga ada dosen dengan kepuasan kerja dan loyalitas kerja relatif tinggi. Adanya sebagian dosen yang memiliki keinginan untuk pindah mengajar ke perguruan tinggi lain selain perguruan tinggi tempat selama ini mereka mengajar, mengindikasikan adanya persoalan serius berkaitan dengan kepuasan kerja dan loyalitas kerja mereka.

Salah satu alasan yang seringkali dikemukakan oleh dosen sehingga muncul kecenderungan untuk pindah perguruan tinggi terkait dengan faktor imbalan dan lingkungan kerja. Sebagian dosen memiliki penilaian kurang baik terhadap kemampuan perguruan tinggi (tempat mereka mengajar) dalam menyediakan imbalan yang layak dan lingkungan kerja yang nyaman bagi mereka sebagai tenaga pengajar. Karena itu, yang menjadi pertanyaan adalah, apakah kepuasan kerja dan loyalitas kerja dosen terkait dengan penilaian mereka terhadap nilai imbalan ataupun kompensasi yang mereka terima dari lingkungan kerja tempat mereka mengajar. Karena itu, penelitian ini menganalisis model peningkatan loyalitas kerja dosen PTS dengan menggunakan kepuasan kerja, imbalan dan lingkungan kerja sebagai predictor variable.

Penggunaan SEM atau Structural Equation Modeling sebagai alat analisis data memungkinkan arah dan sifat hubungan antar variabel dapat diketahui dan dianalisis secara lebih baik demi kepentingan intervensi kebijakan guna meningkatkan loyalitas kerja dari dosen.

\section{Keterkaitan antara Kepuasan dan Loyalitas Kerja}

Loyalitas berkaitan dengan tingkat kepercayaan adalah suatu keinginan untuk melindungi dan menyelamatkan wajah bagi orang lain (Robbins, 2010). Bila seseorang memiliki loyalitas dan kepercayaan terhadap suatu hal, maka orang tersebut bersedia berkorban dan setia terhadap hal yang dipercayainya itu. Jadi, loyalitas memiliki hubungan bersifat positif terhadap tingkat kepercayaan, dimana semakin tinggi tingkat kepercayaan karyawan terhadap perusahaan, maka semakin tinggi pula tingkat loyalitas karyawan tersebut terhadap instansi tempat ia bekerja. Adanya hubungan fungsional antara kepuasan kerja dan loyalitas kerja telah ditemukan oleh sejumlah peneliti sebelumnya. 
Hasan et al. (2013) menemukan bahwa kepuasan kerja memiliki hubungan searah dengan loyalitas kerja pegawai. Hal ini didukung oleh temuan penelitian Waqas et al. (2014) bahwa kepuasan kerja dapat mempengaruhi loyalitas kerja (job loyalty). Sebelumnya, hasil kajian Fischer (2010) juga menemukan bahwa loyalitas karyawan terkait dengan beberapa faktor di antaranya dengan kepuasan kerja.

\section{Keterkaitan antara Lingkungan Kerja dengan Kepuasan dan Loyalitas Kerja}

Lingkungan kerja dapat berpengaruh pada kepuasan kerja dan loyalitas kerja pegawai. Pada umumnya setiap pegawai menginginkan adanya lingkungan kerja yang baik. Semakin baik lingkungan kerja akan semakin tinggi pula kepuasan kerja pegawai. Sehingga penilaian terhadap lingkungan kerja dapat berdampak terhadap kepuasan kerja. Pegawai yang memiliki persepsi baik terhadap lingkungan kerja mereka maka akan cenderung mempertahankan keberadaan diri mereka dalam lingkungan kerja tersebut sehingga berdampak kepada terbentuknya loyalitas kerja yang tinggi.

Adanya pengaruh lingkungan kerja terhadap kepuasan kerja dikemukakan oleh Bakotic dan Tomislav (2013) bahwa terdapat hubungan yang erat antara lingkungan kerja dengan kepuasan kerja karyawan. Hal ini juga diperkuat oleh temuan penelitian Jain dan Kaur (2014) yang menyimpulkan bahwa lingkungan kerja yang baik juga dapat meningkatkan kepuasan kerja. Selanjutnya keterkaitan antara lingkungan kerja dan loyalitas kerja secara empiris sudah dibuktikan oleh temuan penelitian Soegandhi et al. (2013) bahwa kepuasan kerja berpengaruh secara signifikan terhadap loyalitas kerja karyawan. Temuan penelitian Waqas et al. (2014) juga membuktikan bahwa lingkungan tempat kerja (work place environment) memiliki pengaruh yang signifikan terhadap loyalitas kerja.

\section{Keterkaitan antara Imbalan dengan Kepuasan dan Loyalitas Kerja}

Imbalan atau kompensasi yang diterima oleh pegawai tidak hanya berdampak pada kepuasan kerja, tetapi juga dapat berpengaruh pada loyalitas kerja pegawai. Adanya bentuk pengaruh positif dari imbalan terhadap kepuasan kerja dikemukakan oleh Arnold dan Feldman (2009) bahwa gaji memainkan peranan nyata dalam menentukan kepuasan kerja, sebab gaji dapat digunakan sebagai instrumen untuk memenuhi kebutuhan, simbol dari prestasi, dan sumber pengakuan kepada pekerja sebagai refleksi penghargaan atas sumbangan mereka pada organisasi. Secara empiris, adanya pengaruh signifikan kompensasi terhadap kepuasan kerja diperkuat oleh temuan penelitian Soesatyo (2010) yang menyimpulkan bahwa kompensasi berpengaruh signifikan terhadap kepuasan kerja karyawan.

Selanjutnya keterkaitan antara imbalan atau kompensasi dengan loyalitas kerja seperti dikemukakan oleh Steers dan Porter (2013) menyatakan bahwa timbulnya loyalitas kerja dipengaruhi oleh beberapa faktor diantaranya sikap positif terhadap perusahaan, rasa percaya terhadap perusahaan sehingga bisa menimbulkan rasa aman, merasakan adanya kepuasan pribadi yang dapat dipenuhi oleh perusahaan. Kompensasi atau imbalan ada kebutuhan bagi setiap pegawai. Sehingga semakin baik kemampuan instansi dalam memenuhi kebutuhan mereka tidak hanya berdampak pada kepuasan kerja tetapi juga berpengaruh terhadap loyalitas kerja mereka. Hasil kajian empiris yang dilakukan oleh Albahussain (2014) pada sejumlah perusahaan di Saudi Arabia menemukan bahwa kebijakan kompensasi berdampak pada peningkatan loyalitas kerja karyawan. Sebelumnya penelitian yang dilakukan oleh Al-Ma'ani (2013) pada sejumlah perusahaan perbankan di Yordania juga memberikan bukti yang sama bahwa factor kompensasi berdampak positif terhadap loyalitas kerja.

Berdasarkan literatur empiris yang menjelaskan keterkaitan antar variabel seperti dijelaskan sebelumnya, dapat dinyatakan bahwa penelitian ini menempatkan kepuasan kerja dan loyalitas kerja dosen sebagai variabel endogen, dengan lingkungan kerja dan imbalan sebagai variabel eksogen. Selain itu, keberadaan kepuasan kerja juga di- 
posisikan sebagai variabel mediasi antara loyalitas kerja dosen dengan dua variabel eksogen tersebut. Karena itu, paradigma atau kerangka penelitian ini seperti ditunjukkan dalam Gambar 1.

Mengacu pada literatur empiris dan kerangka penelitian sebagaimana telah diuraikan sebelumnya, maka dapat dinyatakan hipotesis yang diuji dalam penelitian ini adalah:
$\mathbf{H}_{1}$ : Kepuasan kerja berpengaruh positif terhadap loyalitas kerja dosen.

$\mathbf{H}_{2}$ : Lingkungan kerja berpengaruh positif terhadap kepuasan kerja dosen.

$\mathbf{H}_{3}$ : Lingkungan kerja berpengaruh positif terhadap loyalitas kerja dosen.

$\mathbf{H}_{\mathbf{4}}$ : Imbalan berpengaruh positif terhadap kepuasan kerja dosen.

$\mathbf{H}_{5}$ : Imbalan berpengaruh positif terhadap loyalitas kerja dosen.

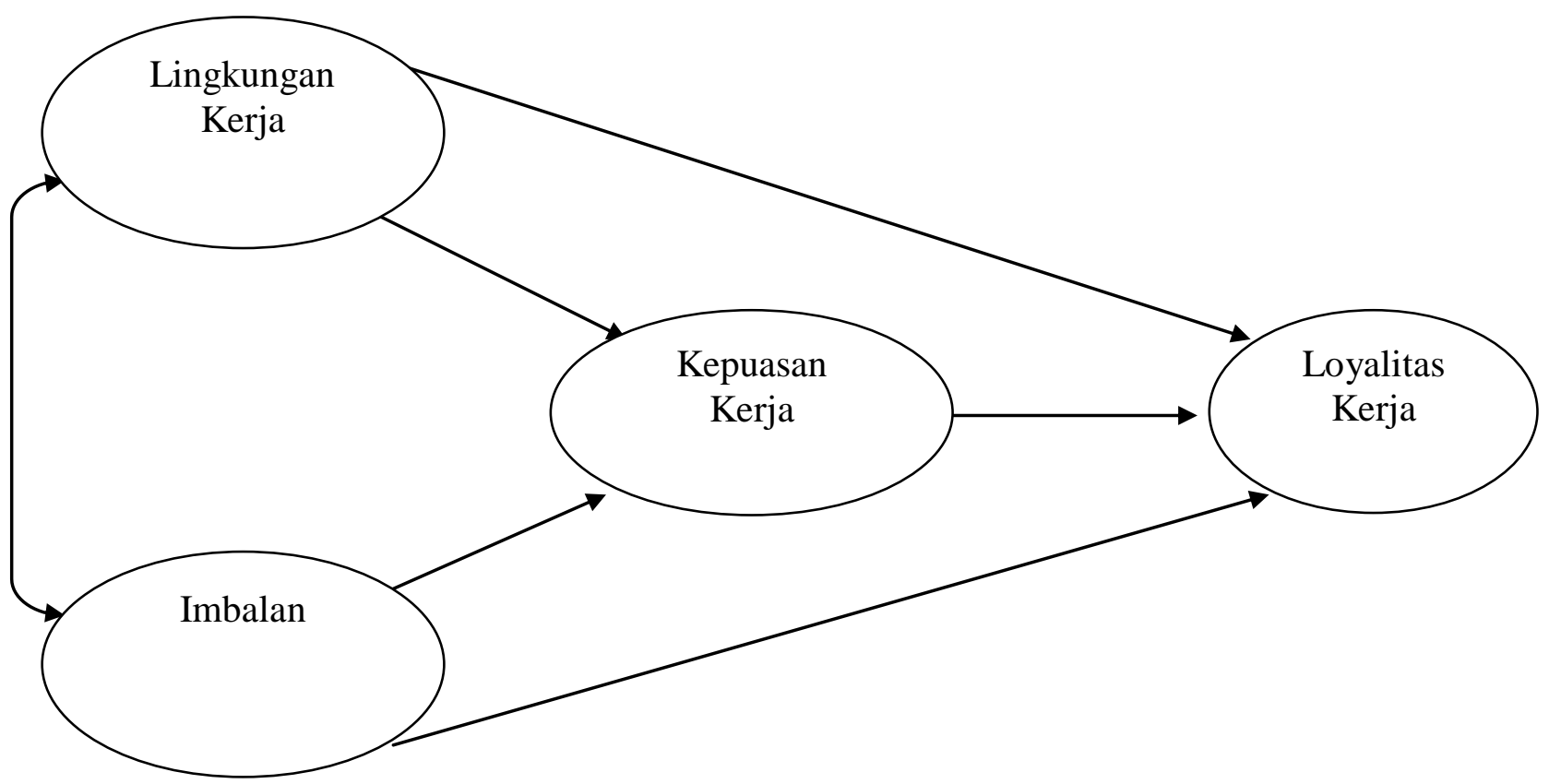

Gambar 1. Kerangka Penelitian

\section{METODE PENELITIAN}

Penelitian ini dilakukan pada lima perguruan tinggi swasta (PTS) di Kota Banda Aceh terdiri dari Universitas Serambi Mekah, Universitas Abulyatama, Universitas Muhamadiyah, Universitas Ubudiyah dan Universitas Iskandar Muda. Objek penelitian berhubungan dengan model peningkatan loyalitas kerja dosen. Variabel yang digunakan untuk memprediksi loyalitas kerja dosen terdiri dari kepuasan kerja, lingkungan kerja dan imbalan.

Populasi penelitian adalah seluruh dosen tetap yayasan yang mengajar pada lima PTS tersebut periode 2019 yang berjumlah 920 orang. Menggunakan rumus Slovin dengan tingkat kelonggaran sebesar 7,5 persen diperoleh jumlah sampel sebanyak 150 orang.
Penentuan jumlah sampel pada masingmasing perguruan tinggi dilakukan secara proporsional sampling.

Pengumpulan data dilakukan melalui pengedaran kuesioner kepada dosen PTS. Kuesioner. Kuesioner adalah pengumpulan data dengan mengedarkan daftar pertanyaan yang berkaitan dengan variabel yang diteliti. Kuesioner itu berisi pernyataan-pernyataan berkaitan dengan indikator-indikator loyalitas kerja, kepuasan kerja, lingkungan kerja, imbalan dan pengetahuan dosen. Setiap pernyataan yang dimuat dalam kuesioner penelitian tersebut disediakan alternatif pilihan jawaban. Dosen diminta untuk memberikan check list $(\sqrt{ })$ pada alternatif pilihan jawaban yang mereka anggap paling sesuai dengan kondisi riil yang mereka 
rasakan atau ketahui. Skala pengukuran yang digunakan adalah skala interval dalam bentuk skala Likert (Likert scale) dengan bobot berkisar antara 1 sampai 5, dengan ketentuan $1=$ sangat tidak setuju, $2=$ tidak setuju, $3=$ ragu-ragu, $4=$ setuju dan $5=$ sangat setuju (Amri \& Surya, 2013; Amri et al, 2018).

Sesuai dengan penjelasan sebelumnya, pada dasarnya penelitian ini mengoperasionalkan empat variabel yang diukur, yaitu loyalitas kerja, kepuasan kerja, lingkungan kerja, dan imbalan. Loyalitas kerja dosen terdiri dari 5 (lima) indikator meliputi tidak ingin pindah ke PTS lain, bersedia bekerja secara sungguh-sungguh, perasaan bangga menjadi dosen, bersedia mengabaikan kepentingan pribadi demi kemajuan PTS, dan adanya kesamaan nilai yang dianut dosen dengan nilai-nilai yang berlaku pada PTS. Variabel kepuasan kerja dosen terdiri dari 5 (lima) indikator meliputi: pengakuan yang diperoleh sebagai dosen, perhatian yang didapatkan dari yayasan, hubungan antara yayasan dan dosen, hubungan antara sesama dosen dan pengelolaan kampus oleh yayasan. Variabel lingkungan kerja terdiri dari 5 (lima) indikator meliputi keterlibatan, orientasi tugas, tekanan pekerjaan, kejelasan peran dan tanggung jawab, serta dukungan fasilitas fisik. Variabel imbalan terdiri dari 5 (lima) indikator meliputi: gaji pokok, tunjangan jabatan, program BPJS, peluang karir dan kompensasi finansial lainnya yang diperoleh.

Penelitian ini menggunakan pendekatan kuantitatif dengan desain kausalitas, yakni menguji dan menganalisis hubungan sebab akibat antara loyalitas kerja dosen dengan tiga predictor variable meliputi kepuasan kerja, lingkungan kerja, dan imbalan. Penggunaan desain kausalitas akan dapat memberikan jawaban tentang arah dan signifikansi pengaruh masing-masing predictor variable terhadap loyalitas kerja dosen. Peralatan analisis data yang digunakan adalah structural equation model (SEM) dengan AMOS 21.

\section{HASIL ANALISIS}

\section{Hasil Confirmatory Factor Analysis}

Dalam penelitian ini, variabel atau konstruk yang diteliti terdiri dari loyalitas kerja, kepuasan kerja, lingkungan kerja dan imbalan. Analisis konfirmatori dimaksudkan untuk menguji apakah indikator-indikator yang digunakan untuk mengukur masingmasing variabel mampu memanifestasikan variabel yang diukur. Dengan kata lain, analisis CFA juga berguna untuk menentukan apakah suatu indikator pengukuran yang digunakan mengukur variabel apakah bisa dinyatakan valid atau tidak.

Secara statistik, suatu indikator dapat dinyatakan sebagai manifestasi dari variabel yang diukur apabila memiliki nilai loading factor $>0,70$, nilai critical ratio $(\mathrm{CR})>2,00$ dan $p$-value $<0,05$ (Ghozali, 2011). Ketika suatu indikator tidak memenuhi kriteria tersebut, maka indikator tersebut direduksi dari model dan kemudian uji CFA dilanjutkan kepada tahap selanjutnya hingga semua indikator atau variabel manifest tersebut memenuhi kriteria yang telah ditentukan.

Hasil uji CFA tahap pertama menunjukkan nilai loading factor masingmasing indikator pada setiap variabel penelitian berbeda satu sama lain.Variabel loyalitas kerja misalnya, terdiri dari lima indikator disimbolkan dengan Loy1, Loy2 hingga Loy5. Nilai loading factor untuk indikator pertama dan kedua (Loy1 dan Loy2) masing-masing sebesar 0,763 dan 0,782, lebih besar dari 0,70. Hal ini mengindikasikan kedua indikator tersebut sudah memenuhi nilai yang telah dipersyaratkan sehingga dapat dimasukkan dalam uji tahap selanjutnya.

Sebaliknya indikator ketiga (Loy3) memiliki nilai loading factor sebesar 0,694 lebih kecil 0,70. Mengacu pada ketentuan nilai loding factor, indikator tersebut dinyatakan tidak dapat memanifestasikan loyalitas kerja. Kemudian indikator keempat dan kelima (Loy 4 dan Loy5) masing-masing memiliki nilai loading factor sebesar 0,771 dan 0,764, lebih besar dari 0,70. Untuk lebih jelasnya mengenai nilai loading factor hasil uji CFA tahap pertama dapat dilihat Tabel 1.

Berdasarkan Tabel 1 dapat diidentifikasikan bahwa indikator yang digunakan untuk mengukur variabel imbalan disimbol kan dengan $\operatorname{Im} 1, \operatorname{Im} 2$ hingga $\operatorname{Im} 5$, seluruhnya memiliki nilai loading factor di atas 0,70 . Hal ini berarti bahwa kelima indikator tersebut 
mampu memanifestasikan penilaian dosen terhadap imbalan yang mereka terima. Selanjutnya variabel lingkungan juga memiliki lima indikator disimbolkan dengan LK1, LK2 hingga LK5.

Nilai loading factor untuk masingmasing indikator tersebut juga lebih besar dari 0,70. Mengacu pada nilai loading factor tersebut juga dapat diartikan bahwa kelima indikator merupakan manifestasi lingkungan kerja, sehingga bisa digunakan untuk mengukur penilaian dosen terhadap lingkungan kerja mereka. Selanjutnya variabel kepuasan kerja juga memiliki lima indikator yang disimbolkan dengan KK1, KK2 hingga KK5. Nilai loading factor masing-masing variabel juga lebih besar dari 0,70. Artinya, seluruh indikator yang digunakan untuk mengukur kepuasan kerja merupakan manifestasi dari variabel tersebut. Dengan kata lain, seluruh indikator dapat mengukur fenomena yang berkaitan dengan kepuasan kerja dosen.

Sebagaimana dijelaskan sebelumnya, terdapat satu indikator yang memiliki nilai loading factor dibawah 0,70 yakni indikator ketiga berkaitan dengan loyalitas kerja (Loy3). Sedangkan pengujian full structural model SEM mensyaratkan agar semua indikator memiliki nilai loading factor di atas 0,70. Karena itu, indikator tersebut direduksi untuk uji CFA tahap berikutnya. Hasil uji CFA tahap kedua seperti ditunjukkan dalam Tabel 2.

Tabel 1. Hasil Confirmatory Factor Analysis Tahap Pertama

\begin{tabular}{|c|c|c|c|c|c|}
\hline & & & Loading Factor & Critical Ratio & p-value \\
\hline IM1 & $<---$ & Imbalan & .773 & & \\
\hline IM2 & $<--$ & Imbalan & .726 & 8.612 & $* * *$ \\
\hline IM3 & $<---$ & Imbalan & .731 & 8.689 & $* * *$ \\
\hline IM4 & $<--$ & Imbalan & .801 & 9.590 & $* * *$ \\
\hline IM5 & $<---$ & Imbalan & .707 & 8.374 & $* * *$ \\
\hline LK5 & $<--$ & Lingkungan_Kerja & .821 & & \\
\hline LK4 & $<--$ & Lingkungan_Kerja & .812 & 10.847 & $* * *$ \\
\hline LK3 & $<--$ & Lingkungan_Kerja & .801 & 10.651 & $* * *$ \\
\hline LK2 & $<---$ & Lingkungan_Kerja & .797 & 10.583 & $* * *$ \\
\hline LK1 & $<---$ & Lingkungan_Kerja & .724 & 9.325 & $* * *$ \\
\hline KK5 & $<---$ & Kepuasan_Kerja & .797 & & \\
\hline KK4 & $<---$ & Kepuasan_Kerja & .829 & 10.858 & $* * *$ \\
\hline KK3 & $<---$ & Kepuasan_Kerja & .808 & 10.513 & $* * *$ \\
\hline KK2 & $<---$ & Kepuasan_Kerja & .741 & 9.415 & $* * *$ \\
\hline KK1 & $<--$ & Kepuasan_Kerja & .817 & 10.661 & $* * *$ \\
\hline LOY5 & $<---$ & Loyalitas_Kerja & .764 & & \\
\hline LOY4 & $<---$ & Loyalitas_Kerja & .771 & 9.413 & $* * *$ \\
\hline LOY3 & $<---$ & Loyalitas_Kerja & .694 & 8.349 & $* * *$ \\
\hline LOY2 & $<--$ & Loyalitas_Kerja & .782 & 9.572 & $* * *$ \\
\hline LOY1 & $<--$ & Loyalitas_Kerja & .763 & 9.307 & $* * *$ \\
\hline
\end{tabular}

Ket: $* * *=0.001$

Sumber: Data Primer Diolah, 2019 
Tabel 2. Hasil Confirmatory Factor Analysis Tahap Kedua

\begin{tabular}{|c|c|c|c|c|c|}
\hline & & & Loading Factor & Critical Ratio & $p$-value \\
\hline IM1 & $<---$ & Imbalan & .773 & & \\
\hline IM2 & $<---$ & Imbalan & .728 & 8.652 & $* * *$ \\
\hline IM3 & $<---$ & Imbalan & .729 & 8.669 & $* * *$ \\
\hline IM4 & $<--$ & Imbalan & .801 & 9.603 & $* * *$ \\
\hline IM5 & $<---$ & Imbalan & .707 & 8.373 & $* * *$ \\
\hline LK4 & $<---$ & Lingkungan_Kerja & .810 & 9.225 & $* * *$ \\
\hline LK3 & $<---$ & Lingkungan_Kerja & .800 & 9.111 & $* * *$ \\
\hline LK2 & $<--$ & Lingkungan_Kerja & .798 & 9.083 & $* * *$ \\
\hline LK1 & $<---$ & Lingkungan_Kerja & .725 & & \\
\hline KK5 & $<---$ & Kepuasan_Kerja & .798 & & \\
\hline KK4 & $<---$ & Kepuasan_Kerja & .826 & 10.824 & $* * *$ \\
\hline KK3 & $<--$ & Kepuasan_Kerja & .807 & 10.503 & $* * *$ \\
\hline KK2 & $<---$ & Kepuasan_Kerja & .742 & 9.450 & $* * *$ \\
\hline KK1 & $<---$ & Kepuasan_Kerja & .819 & 10.711 & $* * *$ \\
\hline LOY5 & $<---$ & Loyalitas_Kerja & .771 & & \\
\hline LOY4 & $<---$ & Loyalitas_Kerja & .754 & 9.201 & $* * *$ \\
\hline LOY2 & $<---$ & Loyalitas_Kerja & .783 & 9.603 & $* * *$ \\
\hline LOY1 & $<---$ & Loyalitas_Kerja & .766 & 9.370 & $* * *$ \\
\hline LK5 & $<--$ & Lingkungan_Kerja & .822 & 9.352 & $* * *$ \\
\hline IM1 & $<--$ & Imbalan & .773 & & \\
\hline
\end{tabular}

Ket: $* * *=0.001$

Sumber: Data Primer Diolah, 2019

Berdasarkan Tabel 2 dapat dilihat bahwa semua kriteria pengujian confirmatory factor analysis (CFA) sudah terpenuhi, dimana semua indikator memiliki nilai loading factor di atas 0,70 , nilai critical ratio (CR) di atas 2,00 dan p-value di bawah 0,05. Artinya indikator-indikator untuk setiap variabel seperti ditunjukkan dalam tersebut adalah indikator-indikator yang dinilai mampu mengkonfirmasi variabel yang diteliti.

\section{Hasil Measurement Model}

Sesuai dengan kerangka konsep penelitian, variabel endogen dalam penelitian ini terdiri dari dua variabel meliputi kepuasan kerja dan loyalitas kerja dosen. Selanjutnya variabel eksogen terdiri dari imbalan dan lingkungan kerja. Ukuran goodness of fit (kebaikan model) dalam SEM menggunakan beberapa pengukuran terdiri dari $\mathrm{X}^{2}$ atau $c h i$ square statistik, GFI (Goodness of Fit Index), AGFI (Adjusted Goodness of Fit Index) TLI (Tucker Lewis Index), CFI (Comparative Fit Index) dan RMSEA (Root Mean Square Error of Appoximation), dengan ketentuan $\mathrm{X}_{\text {stat }}^{2}<\mathrm{X}^{2}$ tab, probability $\geq 0,05$, GFI $\geq$ 0,90, AGFI $\geq 0,90$, TLI $\geq 0,95$, CFI $\geq 0,95$, dan RMSEA $\leq 0,08$ (Ghozali, 2011).

Sesuai dengan tahapan CFA, uji terhadap measurement model juga dilakukan dua tahap. Pada uji tahap pertama terdapat beberapa kriteria yang belum memenuhi persyaratan seperti chi-square statistik > chisquare tabel, probability $<0,05$, dan nilai GFI dan AGFI masing-masing lebih kecil dari 0,90. Sebaliknya, ukuran lain seperti TLI, CFI 
dan RMSEA telah terpenuhi. Untuk lebih jelasnya mengenai measurement model tahap pertama dan kedua seperti ditunjukkan dalam Tabel 3 Sesuai dengan tahapan CFA, uji terhadap measurement model juga dilakukan dua tahap. Pada uji tahap pertama terdapat beberapa kriteria yang belum memenuhi persyaratan seperti chi-square statistik >chisquare tabel, probability $<0,05$, dan nilai GFI dan AGFI masing-masing lebih kecil dari 0,90. Sebaliknya, ukuran lain seperti TLI, CFI dan RMSEA telah terpenuhi. Untuk lebih jelasnya mengenai measurement model tahap pertama dan kedua seperti ditunjukkan dalam Tabel 3.

Berdasarkan Tabel 3 dapat dilihat nilai $\mathrm{X}^{2}$ hitung sebesar 117,215 . Sedangkan nilai $\mathrm{X}^{2}$ tabel pada df $=146$ sebesar 175,198 lebih besar bila dibandingkan dengan nilai $\mathrm{X}^{2}$ hitung. Dengan kata lain, nilai $X^{2}{ }_{\text {hit }}<X^{2}$ tab $(117,215<145,405)$. Hal ini berarti bahwa nilai statistik $\mathrm{X}^{2}$ hitung sudah memenuhi kriteria yang telah ditentukan, sehingga model dinyatakan tidak baik.
Nilai probability atau p-value hasil measurement model pada tahap kedua ini sebesar 0,067 juga sudah memenuhi kriteria yang telah ditentukan yakni di atas 0,05 . Hal ini berarti bahwa dilihat dari nilai $p$-value, hasil measurement model sudah memenuhi ketentuan goodness of fit index. Selanjutnya berdasarkan kriteria nilai GFI juga sudah memenuhi syarat yakni sebesar 0,951 lebih besar dari nilai yang dipersyaratkan sebesar 0,90 . Demikian juga halnya dengan nilai AGFI sebesar 0,952 juga lebih besar dari 0,90. Nilai TLI dan RMSEA juga sudah memenuhi persyaratan yakni masing-masing sebesar 0,973 $(>0,95)$ dan 0,042 $(<0,08)$.

Berdasarkan uraian tersebut maka jelaslah bahwa hasil pengujian measurement model menunjukkan bahwa semua kriteria sudah terpenuhi pada uji tahap kedua. Sehingga langkah berikutnya dapat dilanjutkan kepada full structural model guna menguji hubungan kausalitas antar variabel sesuai dengan paradigma penelitian yang telah dibuat sebelumnya.

Tabel 3. Hasil Measurement Model

\begin{tabular}{ccccc}
\hline $\begin{array}{c}\text { Tahapan } \\
\text { Pengujian }\end{array}$ & Goodness-of-Fit Index & Kriteria Nilai & Hasil & Evaluasi Model \\
\hline \multirow{5}{*}{$\begin{array}{c}\text { Tahap } \\
\text { Pertama }\end{array}$} & $\chi^{2}$ - Chi-square & $\mathrm{X}^{2}{ }_{\text {hit }}<\mathrm{X}^{2}$ tab & $230,716>194,883$ & Belum Baik \\
\cline { 2 - 5 } & Significance Probability & $\geq 0,05$ & 0,000 & Belum baik \\
\cline { 2 - 5 } & GFI & $\geq 0,90$ & 0,865 & Belum baik \\
\cline { 2 - 5 } & AGFI & $\geq 0,90$ & 0,827 & Belum baik \\
\cline { 2 - 5 } & TLI & $\geq 0,95$ & 0,959 & Baik \\
\cline { 2 - 5 } & CFI & $\leq 0,95$ & 0,953 & Baik \\
\cline { 2 - 5 } & RMSEA & $\geq 0,08$ & 0,054 & Baik \\
\cline { 2 - 5 } Tahap & Significance Probability & $\geq 0,90$ & 0,067 & Baik \\
\cline { 2 - 5 } Kedua & GFI & $\geq 0,90$ & 0,951 & Baik \\
\cline { 2 - 5 } & AGFI & $\geq 0,95$ & 0,932 & Baik \\
\cline { 2 - 5 } & CFI & $\geq 0,95$ & 0,956 & Baik \\
\cline { 2 - 5 } & TLI & $\leq 0,08$ & 0,973 & Baik \\
\cline { 2 - 5 } & RMSEA & 0,042 & \\
\cline { 2 - 5 } & & & $117,215<175,198$ & \\
\hline
\end{tabular}

Sumber: Data Primer Diolah, 2019 


\section{Hasil Full Structural Model}

Setelah measurement model yang di analisis melalui analisis faktor konfirmatori dan dilihat bahwa masing-masing indikator dapat digunakan untuk mendefinisikan sebuah konstruk laten, maka langkah selanjutnya dalam penggunaan Structural Equition Model (SEM) sebagai peralatan analisis data adalah melakukan uji struktural terhadap keseluruhan model. Dalam hal ini peneliti secara langsung melakukan uji keterkaitan antara seluruh variabel (konstruk) yang diteliti dengan melibatkan seluruh indikator pada masingmasing konstruk. Hasil full structural model yang menjelaskan keterkaitan antara seluruh variabel penelitian seperti terlihat dalam Gambar 2.

Gambar 2 tidak hanya memperlihatkan nilai koefisien estimasi masing-masing variabel eksogen terhadap variabel endogen, tetapi juga memperlihatkan nilai loading factor dari masing-masing indikator (manifest variable) terhadap variabel tersebut Nilai koefisien estimasi lingkungan kerja dan imbalan terhadap kepuasan kerja dan loyalitas kerja dosen seperti dalam Tabel 4.

Berdasarkan Tabel 4 dapat dipahami bahwa lingkungan kerja dan imbalan memiliki pengaruh positif dan signifikan terhadap kepuasan kerja dan loyalitas kerja dosen. Semakin baik persepsi dosen terhadap lingkungan kerja dan imbalan akan semakin pula kepuasan dan loyalitas kerja mereka pada perguruan tinggi tempat dimana mereka mengajar. Dosen yang merasakan adanya orientasi tugas yang lebih baik, tekanan pekerjaan yang tidak terlalu berat dan adanya kejelasan peran dan tanggung jawab sebagai tenaga pengajar serta dukungan fasilitas kerja fisik yang lebih baik cenderung menemukan kepuasan dalam bekerja. Pada gilirannya kondisi tersebut berdampak pada loyalitas kerja mereka.

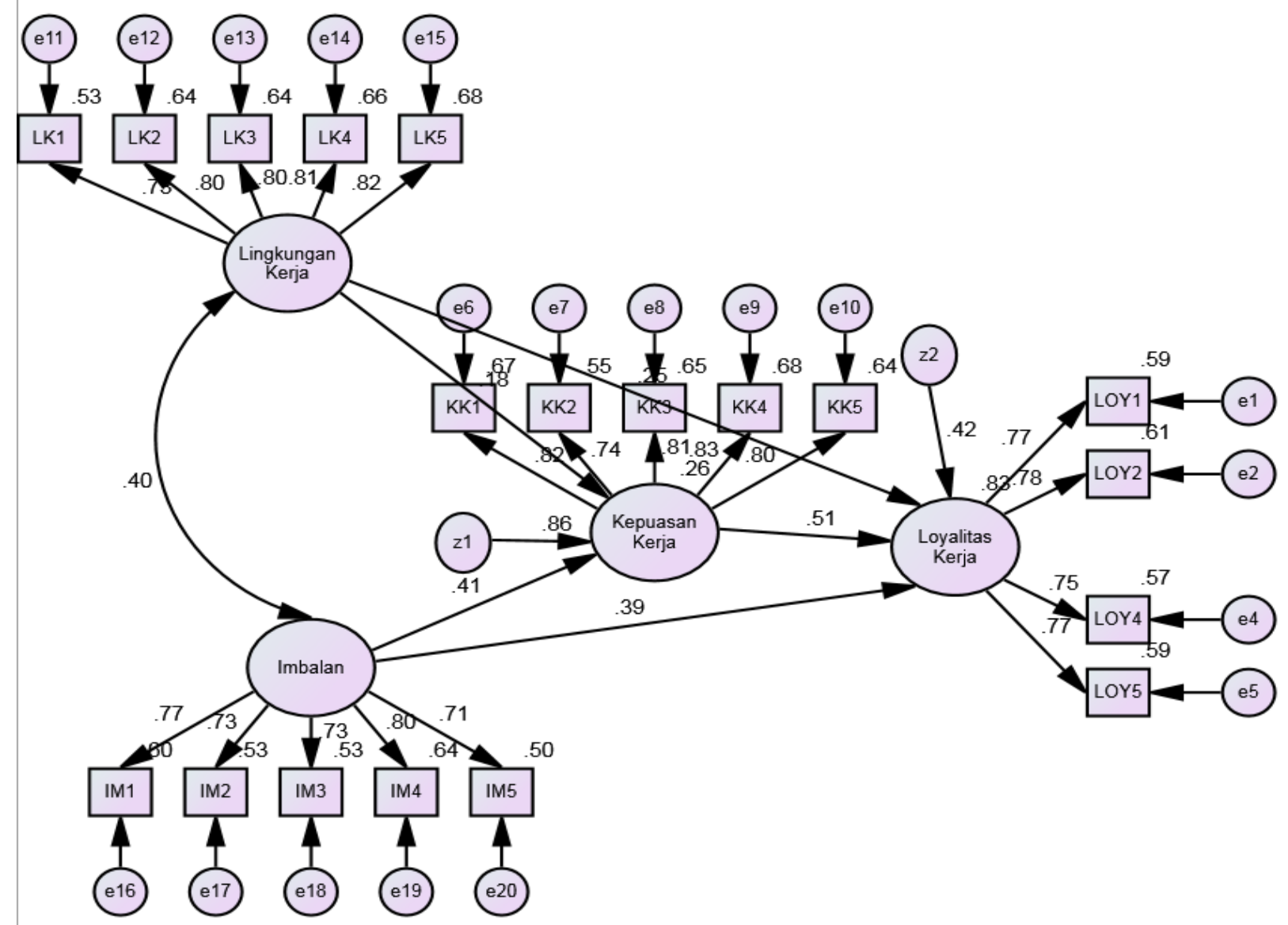

Sumber: Data Primer Diolah, 2019

Gambar 2. Hasil Full Structural Model 
Tabel 4. Koefisien Estimasi Masing-masing Variabel

\begin{tabular}{lllccc}
\hline & & & Estimate & C.R. & P \\
\hline Kepuasan_Kerja & $<---$ & Imbalan & .409 & 3.959 & $* * *$ \\
Kepuasan_Kerja & $<---$ & Lingkungan_Kerja & .181 & 2.011 & .047 \\
Loyalitas_Kerja & $<---$ & Imbalan & .389 & 4.700 & $* * *$ \\
Loyalitas_Kerja & $<---$ & Kepuasan_Kerja & .512 & 6.293 & $* * *$ \\
Loyalitas_Kerja & $<---$ & Lingkungan_Kerja & .246 & 3.565 & $* * *$ \\
\hline
\end{tabular}

Ket: $* * *=0.001$

Sumber: Data Primer Diolah, 2019

Seperti ditunjukkan dalam Tabel 4, kepuasan juga berpengaruh secara langsung terhadap loyalitas kerja dosen. Kepuasan kerja diperoleh dosen ketika pihak yayasan perguruan tinggi memberikan perhatian terhadap kepentingan mereka, adanya pola hubungan yang baik antara dosen dan pihak yayasan serta adanya pengakuan terhadap mereka yang diwujudkan dalam bentuk sikap saling menghargai satu sama lain. Kondisi seperti ini juga dapat membuat mereka berusaha untuk bersungguh-sungguh dalam menjalankan tugas sebagai dosen yayasan.

Mengacu pada Gambar 2, dapat dipahami bahwa keberadaan kepuasan kerja dapat dimaknai sebagai variabel intervening (perantara) antara lingkungan kerja dan imbalan di satu sisi dengan loyalitas kerja dosen di sisi lain. Dengan kata lain, pengaruh lingkungan kerja dan imbalan terhadap loyalitas kerja dosen tidak hanya terjadi secara langsung, tetapi juga melalui kepuasan kerja sebagai variabel perantara.

\section{Pembahasan}

Pada bagian ini akan ditelaah lebih mendalam mengenai tiga jalur pengaruh, yaitu pengaruh kepuasan terhadap loyalitas kerja, pengaruh lingkungan kerja terhadap kepuasan dan loyalitas kerja, serta pengaruh imbalan terhadap kepuasan dan loyalitas kerja.

\section{Analisis Pengaruh Kepuasan terhadap Loyalitas Kerja}

Kepuasan kerja berpengaruh positif dan signifikan terhadap loyalitas kerja dosen, ditunjukkan oleh nilai koefisien estimasi sebesar 0,512 dengan nilai p-value sebesar $0,001<0,05$. Pengaruh langsung (direct effect) kepuasan kerja terhadap loyalitas kerja dosen sebesar 26,21 persen. Hal ini berarti bahwa dosen dengan kepuasan kerja lebih tinggi cenderung memiliki loyalitas kerja yang juga lebih tinggi dibandingkan dengan mereka yang memiliki kepuasan kerja yang relatif rendah.

Sebaliknya, ketika seorang dosen secara individu memiliki kepuasan kerja rendah, maka kondisi tersebut berdampak pada penurunan loyalitas kerja dosen yang bersangkutan. Dengan demikian hubungan antara kepuasan kerja dan loyalitas kerja dikalangan dosen PTS bersifat searah atau positif. Berdasarkan uraian tersebut, maka hipotesis pertama $\left(\mathrm{H}_{1}\right)$ yang menyatakan kepuasan kerja berpengaruh positif terhadap loyalitas kerja dosen dapat diterima.

Adanya pengaruh positif dan signifikan kepuasan kerja terhadap loyalitas kerja dosen, mendukung hasil penelitian Hasan et al. (2013) yang menyimpulkan bahwa kepuasan kerja memiliki hubungan searah dengan loyalitas kerja pegawai. Selain itu, temuan ini juga sejalan dengan sejumlah penelitian empiris sebelumnya seperti Waqas et al. (2014) yang menemukan bahwa bahwa kepuasan kerja dapat mempengaruhi loyalitas kerja (job loyalty). Hasil kajian yang dilakukan oleh Hasan et al. (2013) yang menemukan bukti empiris bahwa semakin baik kepuasan kerja akan semakin tinggi pula loyalitas kerja mereka; sebaliknya penurunan kepuasan kerja juga dapat berdampak penurunan loyalitas kerja. 


\section{Analisis Pengaruh Lingkungan Kerja terhadap Kepuasan dan Loyalitas Kerja}

Lingkungan kerja berpengaruh positif dan signifikan terhadap kepuasan kerja dosen, dengan nilai koefisien estimasi sebesar 0,181 dengan nilai $p$-value sebesar $0,047<0,05$. Pengaruh langsung (direct effect) lingkungan kerja terhadap kepuasan kerja sebesar 3,28 persen. Hal ini berarti bahwa dosen yang memiliki penilaian relatif baik terhadap lingkungan kerja mereka, akan memiliki kepuasan kerja lebih tinggi dibandingkan dengan mereka yang memiliki penilaian kurang baik terhadap lingkungan kerja. Semakin baik lingkungan kerja, semakin tinggi kepuasan kerja dosen. Sebaliknya, ketika lingkungan kerja dipersepsikan kurang baik, maka kondisi tersebut berdampak pada penurunan kepuasan kerja. Mengacu pada hasil statistik tersebut, maka hipotesis kedua $\left(\mathrm{H}_{2}\right)$ yang menyatakan lingkungan kerja berpengaruh positif terhadap kepuasan kerja dosen dapat diterima.

Adanya pengaruh positif dan signifikan lingkungan kerja terhadap loyalitas kerja dosen mendukung hasil penelitian Bakotic dan Tomislav (2013) yang juga menyimpulkan adanya hubungan positif dan erat antara kedua variabel tersebut. Temuan ini juga memperkuat hasil kajian yang dilakukan oleh Jain dan Kaur (2014) yang memberikan bukti empiris bahwa lingkungan kerja yang baik juga dapat meningkatkan kepuasan kerja.

Lingkungan kerja juga berpengaruh positif dan signifikan terhadap loyalitas kerja dosen. Hal ini ditunjukkan oleh nilai koefisien estimasi sebesar 0,246 dan p-value sebesar $0,001(<0,05)$. Pengaruh langsung (direct effect) lingkungan kerja terhadap loyalitas kerja dosen sebesar 6,05 persen. Peningkatan persepsi dosen terhadap kualitas lingkungan kerja secara nyata memberi dampak pada peningkatan loyalitas kerja mereka. Hal ini mengindikasikan bahwa lingkungan kerja yang baik menjadi faktor penentu intensitas loyalitas kerja dosen pada perguruan tinggi tempat mereka bekerja. Ketika lingkungan kerja mereka persepsikan kurang baik, maka kondisi tersebut dapat berdampak buruk pada penurunan derajat loyalitas kerja mereka.
Berdasarkan analisis tersebut, maka hipotesis ketiga $\left(\mathrm{H}_{3}\right)$ yang menyatakan Lingkungan kerja berpengaruh positif terhadap loyalitas kerja dosen dapat diterima.

Penelitian ini karenanya membuktikan adanya pengaruh positif dan signifikan lingkungan kerja terhadap loyalitas kerja dosen konsisten dengan hasil penelitian sebelumnya yang dilakukan oleh Soegandhi et al. (2013) bahwa peningkatan kepuasan kerja secara nyata dapat berdampak pada peningkatan loyalitas kerja karyawan. Temuan ini juga sejalan dengan hasil kajian empiris yang dilakukan oleh Waqas et al. (2014) yang juga membuktikan bahwa factor lingkungan tempat kerja (work place environment) berpengaruh signifikan terhadap loyalitas kerja.

\section{Analisis Pengaruh Imbalan terhadap Kepuasan dan Loyalitas Kerja}

Imbalan atau kompensasi yang diterima oleh dosen berpengaruh positif dan signifikan terhadap kepuasan kerja mereka, dengan nilai koefisien estimasi sebesar 0,409 dengan nilai $p$-value sebesar $0,001<0,05$. Pengaruh langsung (direct effect) imbalan terhadap kepuasan kerja sebesar 16,73 persen. Hal ini berarti bahwa dosen yang memiliki penilaian relatif baik terhadap imbalan atau balas jasa yang mereka terima sebagai pengajar di perguruan tinggi, memiliki kepuasan kerja lebih tinggi dibandingkan dengan mereka yang memiliki penilaian kurang baik terhadap imbalan tersebut.

Semakin baik penilaian dosen terhadap imbalan yang mereka terima, semakin tinggi pula kepuasan kerja mereka. Sebaliknya, ketika kompensasi yang mereka terima dianggap tidak mampu memenuhi kebutuhan mereka, maka kondisi tersebut berdampak pada penurunan kepuasan kerja dosen. Mengacu pada hasil statistik tersebut, maka hipotesis keempat $\left(\mathrm{H}_{4}\right)$ yang menyatakan imbalan berpengaruh positif terhadap kepuasan kerja dosen dapat diterima.

Adanya pengaruh positif imbalan terhadap kepuasan kerja mengkonfirmasi pendapat Arnold dan Feldman (2009) yang menyatakan bahwa kompensasi atau imbalan memiliki peran penting dalam menentukan 
kepuasan kerja. Hal ini didasarkan pada alasan bahwa kompensasi merupakan instrumen utama dalam memenuhi kebutuhan hidup karyawan. Selain itu, kompensasi juga simbol dari prestasi kerja dan salah salah satu bentuk pengakuan atas kemampuan kerja yang mereka miliki. Temuan penelitian ini konsisten dengan hasil penelitian empiris Soesatyo (2010) yang menyimpulkan bahwa kompensasi berpengaruh signifikan terhadap kepuasan kerja karyawan.

Imbalan juga berpengaruh positif dan signifikan terhadap loyalitas kerja dosen. Hal ini ditunjukkan oleh nilai koefisien estimasi sebesar 0,389 dan p-value sebesar 0,001 (< 0,05). Pengaruh langsung (direct effect) imbalan terhadap loyalitas kerja dosen sebesar 15,13 persen. Semakin baik penilaian dosen terhadap kompensasi yang mereka terima sebagai pengajar di perguruan tinggi seperti gaji pokok, tunjangan fungsional dan lain sebagainya, semakin tinggi pula loyalitas kerja mereka pada perguruan tinggi tempat mereka mengajar.

Sebaliknya, ketika kompensasi yang mereka terima adalah dipersepsikan kurang mencukupi, maka kondisi tersebut berdampak nyata pada penurunan loyalitas kerja. Hal ini secara empiris mengindikasikan bahwa kompensasi merupakan faktor penentu utama tingkat kesetiaan dosen pada lembaga pendidikan tempat mereka mengajar. Berdasarkan analisis tersebut, maka hipotesis kelima $\left(\mathrm{H}_{5}\right)$ yang menyatakan imbalan berpengaruh positif terhadap loyalitas kerja dosen dapat diterima.

Hasil penelitian ini mengkofirmasi pendapat Steers dan Porter (2013) yang menyatakan bahwa loyalitas kerja juga dipengaruhi oleh beberapa faktor diantaranya sikap positif terhadap perusahaan, rasa percaya terhadap perusahaan sehingga menimbulkan rasa aman, merasakan adanya kepuasan pribadi yang dapat dipenuhi oleh perusahaan. Kompensasi atau imbalan ada kebutuhan bagi setiap pegawai. Sehingga semakin baik kemampuan instansi dalam memenuhi kebutuhan mereka tidak hanya berdampak pada kepuasan kerja tetapi juga berpengaruh terhadap loyalitas kerja mereka.

\section{KESIMPULAN}

Lingkungan kerja dan imbalan terbukti berpengaruh positif dan signifikan terhadap kepuasan kerja dosen PTS. Semakin baik penilaian dosen terhadap lingkungan kerja pada perguruan tinggi tempat mereka bekerja dan semakin baik penilaian terhadap kompensasi/imbalan yang mereka terima semakin tinggi pula kepuasan kerja dosen. Dengan demikian dapat disimpulkan bahwa peningkatan kepuasan kerja seseorang dosen terkait dengan intervensi kebijakan perguruan tinggi sehubungan dengan upaya penyediaan lingkungan kerja dan kompensasi bagi dosen.

Lingkungan kerja dan imbalan juga berpengaruh positif dan signifikan terhadap loyalitas kerja dosen PTS. Semakin baik penilaian dosen terhadap lingkungan kerja pada perguruan tinggi tempat mereka bekerja dan semakin baik penilaian terhadap kompensasi/imbalan yang mereka terima semakin tinggi pula loyalitas kerja dosen. Sebaliknya, ketika dosen memiliki penilaian yang kurang baik terhadap lingkungan kerja dan imbalan/kompensasi, maka kondisi tersebut berdampak pada penurunan loyalitas kerja mereka. Dengan kata lain, loyalitas kerja dosen sangat ditentukan oleh penilaian mereka terhadap lingkungan kerja dan kompensasi yang disediakan perguruan tinggi sebagai balas jasa atas pengorbanan yang mereka berikan untuk mendukung kelancaran proses belajar mengajar di perguruan tinggi tersebut.

Mengacu pada kesimpulan tersebut, maka yang menjadi saran dan rekomendasi penelitian ini adalah, pimpinan PTS di Banda Aceh sebaiknya melakukan bentuk intervensi kebijakan yang berorientasi pada perbaikan lingkungan kerja dosen dan peningkatan kompensasi bagi tenaga pengajar di lingkungan perguruan tinggi yang dipimpinnya. Secara teknis, hal itu harus dikomunikasikan dengan pihak yayasan (pemilik PTS), mengingat kebijakan terhadap kedua hal tersebut biasanya juga tidak terlepas dari goodwill pihak yayasan. Secara operasional, perbaikan lingkungan kerja dapat dilakukan melalui penyediaan peralatan kerja yang lebih baik bagi setiap dosen terutama ruangan kerja 
dosen dan media pendukung kegiatan belajar mengajar. Selanjutnya perbaikan kompensasi harus menjadikan kebutuhan hidup layak dosen sebagai pertimbangan utama.

\section{UCAPAN TERIMA KASIH}

Kami sebagai peneliti mengucapkan terima kasih yang sebesar-besarnya kepada Ditjen Penguatan Riset dan Pengembangan Kementerian Riset, Teknologi dan Pendidikan Tinggi sebagai penyandang dana penelitian pada skema Penelitian Dosen Pemula (PDP) tahun 2019, dan tidak lupa pula kepada LP2M Sekolah Tinggi Ilmu Ekonomi (STIE) Sabang, Banda Aceh yang telah ikut mendorong serta memfasilitasi kelancaran proses penelitian ini.

\section{DAFTAR PUSTAKA}

Albahussain, S.A. 2014. The Impact of Human Resources Management Activities on Employees Loyalty in Private Organizations in Saudi Arabia. Journal of Economics, Business and Management. Vol. 2, No. 1, hal. 31-37. Al-Ma'ani, A.I. 2013. Factors Affecting the Organizational Loyalty of Workers in the Jordanian Commercial Banks. Institute of Interdisciplinary Business Research. Vol. 4, No. 12, hal. 878-896.

Amri, K. dan Surya, J. 2013. Kajian Perilaku Mahasiswa dalam Menggunakan Internet dengan Pendekatan Technology Acceptance Model (TAM), Jurnal Penelitian Pos dan Informatika. Vol. 3, No. 1, hal. 67-80.

Amri, K., Qurratul'aini, I. dan Julianty. 2018. Preferensi Nasabah Memilih Produk Pembiayaan Bank Aceh Syariah di Kota Banda Aceh. Jurnal Samudra Ekonomi dan Bisnis. Vol. 9, No. 1, hal. 31-41.

Arnold, M. dan Feldman, J. 2009. Human

Resources Management. New York: Prentice Hall, Ltd.

Bakotic, D. dan Tomislav, B. 2013. Relationship between Working Conditions and Job Satisfaction: The Case of Croatian Shipbuilding
Company. International Journal of Business and Social Science. Vol. 4, No. 2, hal. 208-213.

Chen, J.L. 2014. Effect of Knowledge Management and Job Satisfaction on Organizational Loyalty of the Hospital Administrative Staffs. International Journal of Information and Management Sciences. Vol. 2, No. 5, hal. 17-33.

Fischer, J. 2010. Rewarding Employee Loyalty: An Organizational Justice Approach. International Journal of Organisational Behaviour. Vol. 8, No. 3, hal. 486-503.

Ghozali, I. 2011. Structural Equation Modelling, Metode Alternatif Dengan Partial Least Square PLS, Semarang: Badan Penerbit Universitas Diponegoro. Hasan, M.U., Nawaz., M.S., Abbas, G. dan Sajid, M.I. 2013. Impact of High Performances Work Practices on Employee Loyalty and Financial Performance through Mediation of Employee Satisfaction: An Empirical Evidence from the Financial Sector of Pakistan. Middle-East Journal of Scientific Research. Vol. 16, No. 8, hal. 1037-1046.

Jain, R. dan Kaur, S. 2014. Impact of Work Environment on Job Satisfaction. International Journal of Scientific and Research Publications. Vol. 4, No. 1, hal. 1-8.

Kreitner, R. dan Kanicki, A. 2012. Perilaku Organisasi: Organizational Behavior. Buku I, Edisi 8. Alihbahasa: Ely Suandy. Jakarta: Salemba Empat.

Robbins, S.P. 2010. Perilaku Organisasi. Edisi kesepuluh. Edisi Terjemahan. Jakarta: PT Indeks.

Sawitri, A, dan Utomo. 2012. Analisis terhadap Model Pengaruh Kepuasan Bekerja dan Komitmen Berorganisasi pada Kinerja (Studi terhadap Tenagatenaga Ahli Konsultan Perencanaan dan Pengawasan Jalan dan Jembatan di Jawa Timur). Prosiding. Seminar Nasional Manajemen Teknologi V. 
Soegandhi, V.M., Sutanto, M. dan Setiawan, R. 2013. Pengaruh Kepuasan Kerja dan Loyalitas Kerja terhadap Organizational Citizenship Behavior pada Karyawan PT. Surya Timur Sakti Jatim. AGORA. Vol. 1, No. 1, hal. 98-109.

Soesatyo, Y. 2010. Persepsi Keadilan Kompensasi dan Kepuasan Kompensasi Pengaruhnya terhadap Kinerja Karyawan PT. H.M. Sampoerna Tbk Surabaya. Junal Aplikasi Manajemen. Vol. 3, No. 3, hal. 45-61.
Steers, R.M. dan Porter, L.W. 2013. Motivational and Work Behavior. New York: McGraw-Hill Book Co.

Waqas, A., Bashir, U., Sattar, M.F., Abdullah, H.M., Hussain, I., Anjum, W., Ali, M.A. dan Arshad, R. 2014. Factors Influencing Job Satisfaction and Its Impact on Job Loyalty. International Journal of Learning \& Development. Vol. 4, No. 2, hal. 141-161. 